\title{
Żydowski samorząd ziemski w Koronie (XVII-XVIII wiek). Źródła, oprac. Adam Kaźmierczyk i Przemysław Zarubin, Księgarnia Akademicka, Kraków 2019, ss. 679.
}

Adam Kaźmierczyk i Przemysław Zarubin należą do najważniejszych dziś badaczy historii Żydów w Polsce, a - co istotne - należą także do zanikającej grupy historyków zainteresowanych dziejami nowożytnymi. Zjawisko kurczenia się studiów nad wiekami dawnymi, choć globalne, jest niestety szczególnie odczuwalne w historiografii polskiej, a wspomagane obsesjami państwowej polityki historycznej przybiera w ostatnich latach coraz groźniejsze rozmiary. Dlatego każda publikacja Kaźmierczyka i Zarubina - właśnie dlatego, że podtrzymuje zainteresowanie tym coraz mniej badanym okresem - jest dla polskiej judaistyki szczególnie cenna. A rozpoczynająca książkę dedykacja „pamięci profesorów Józefa Andrzeja Gierowskiego i Jakuba Goldberga" to nie tylko piękny gest wobec - formalnych i nieformalnych - nauczycieli jednego z autorów (którego uczniem z kolei jest drugi autor), ale przede wszystkim hołd należny dwóm ścieżkom rozwoju badań nad historią Żydów w dawnej Rzeczypospolitej: polskiej, reprezentowanej przez Józefa Andrzeja Gierowskiego, i żydowskiej, uosabianej (w dużym stopniu także ukształtowanej) przez Jakuba Goldberga.

Najnowsza książka Adama Kaźmierczyka i Przemysława Zarubina to wynik wieloletniego projektu finansowanego przez Narodowy Program Rozwoju Humanistyki, a poświęconego zbieraniu źródeł historycznych ukazujących funkcjonowanie żydowskich władz samorządowych w Koronie na poziomie regionalnym i centralnym. Sam temat oczywiście nie jest nowy. Zwłaszcza Sejm Czterech Ziem, uznawany -z pewną przesadą - za unikatową strukturę samorządności żydowskiej, był przedmiotem badań od początków profesjonalnej historiografii żydowskiej. Jednak, jak wskazują autorzy omawianego opracowania, zniszczenie jego oryginalnych ksiąg i dużej części archiwaliów z nim związanych sprawiło, że do dziś dzieje Sejmu Czterech Ziem znane są dość słabo, posiadamy jedynie jedną poświęconą temu tematowi monografię, a rozproszone i bardzo 
fragmentaryczne źródła nigdy nie zostały systematycznie przebadane. Pierwszą próbą rekonstrukcji bazy źródłowej na temat Sejmu była publikacja Israela Halperina z 1945 r., rozszerzona, uzupełniona i poprawiona przez Israela Bartala w 1990 r. Próbę radykalnego rozszerzenia bazy źródłowej podjęli Jakub Goldberg i Adam Kaźmierczyk, publikując w 2011 r. 255 dokumentów - głównie po polsku i łacinie - wytworzonych przez władze polskie i Sejm Czterech Ziem między rokiem 1588 i 1767. Omawiana tu publikacja Kaźmierczyka i Zarubina jest bezpośrednią kontynuacją tej ostatniej, zarówno jeśli chodzi o temat, jak i koncepcję oraz konstrukcję tomu.

Żydowski samorzad ziemski w Koronie udostępnia w sumie 256 dokumentów ilustrujących funkcjonowanie żydowskich instytucji samorządowych na poziomie regionalnym i centralnym. Źródła zostały podzielone na trzy części zawierające, odpowiednio, dokumenty władz Rzeczypospolitej (1-113), samorządu żydowskiego (114-155) oraz akta sądowe i varia, które nie dały się przyporządkować do żadnego z poprzednich działów (156-256). W obrębie każdej z tych trzech części źródła uporządkowane zostały chronologicznie, co jest typowym (nie znaczy to, że najszczęśliwszym) układem w polskich publikacjach źródłowych. Ogromna większość dokumentów dotyczy spraw podatkowych i sposobów ich egzekucji, co nie jest w żadnym razie zaskakujące, zważywszy, że pochodzą one z zasobów polskich urzędów państwowych, a więc reprezentują przede wszystkim punkt widzenia władz państwowych zainteresowanych samorządem żydowskim głównie jako instytucją podatkową. Tylko jeden uniwersał królewski (nr 17) z 1667 r. porusza kwestię „pogłosek o fałszywym mesjaszu”, a więc odnosi się do docierającej również do Rzeczypospolitej gorączki sabataizmu. Niestety, pozostałe źródła nie dają nam bezpośredniego wglądu w najbardziej fascynujące aspekty życia społeczności żydowskiej, o których wiemy skądinąd, że były przedmiotem obrad Sejmu i sejmików żydowskich, jak choćby kwestie obyczajowe i mentalnościowe, szerzenie się kabały praktycznej i grup pobożnościowych, zachowania nienormatywne itd.

Zbiór źródłowy został poprzedzony niewielkim wstępem, który nie tylko przedstawia ogólne założenia projektu i zasady publikacji tekstów źródłowych (przygotowanych zresztą wzorowo), ale też pokrótce omawia przyczyny powstania i najważniejsze zmiany w funkcjonowaniu żydowskiego samorządu terytorialnego w Koronie w wieku XVII i XVIII, a także wskazuje na kilka interesujących nowych ustaleń, jakie autorom udało się poczynić dzięki zebranym w omawianym tomie dokumentom. 
Być może najciekawszym nowym ustaleniem jest weryfikacja tezy Majera Bałabana, jakoby podstawowym powodem podziału wielkich ziemstw na mniejsze jednostki terytorialne i wydzielania się gmin metropolitalnych były tendencje rozłamowe mniejszych ośrodków miejskich i ich elit. Nowe źródła pozwoliły Kaźmierczykowi i Zarubinowi na wywrócenie tej hipotezy do góry nogami: przynajmniej niekiedy to wielkie gminy metropolitalne uciekały od odpowiedzialności za mniejsze ośrodki miejskie i to im głównie zależało na wydzieleniu się z wielkiego ziemstwa, by nie być obciążanymi obowiązkiem ściągania podatków z pozostałych gmin ziemstwa. Nie znaczy to oczywiście, że tendencje decentralizacyjne nie istniały w mniejszych centrach władzy i że nie były zasilane ambicjami owych mniejszych ośrodków i ich właścicieli. Kaźmierczyk i Zarubin dają przykłady takich procesów na Podolu, w ziemstwie chełmsko-bełskim (z którego wydzieliła się Ordynacja Zamojska) czy w ziemstwie krakowsko-sandomierskim.

Równie ciekawe są spostrzeżenia autorów o stopniowym przejmowaniu obowiązków egzekucji podatków przez nieżydowskich deputatów wojskowych i o dynamice tego procesu, znacznie szybszego od końca XVII w. Dość paradoksalnie prowadziło to do przejęcia podstawowej z punktu widzenia państwa polsko-litewskiego funkcji samorządu żydowskiego przez nieżydowskie organy administracyjne, a więc do podważenia sensowności samego istnienia Sejmu i sejmików żydowskich. Mimo podjętej w $1717 \mathrm{r}$. próby reformy systemu opodatkowania ludności żydowskiej pozostał on niewydolny i nieefektywny, co ostatecznie doprowadziło do jego upadku i rozwiązania instytucji żydowskiego samorządu terytorialnego w 1764 r.

Niestety, ten niezwykle interesujący wstęp to zaledwie kilkanaście stron bardzo szkicowego omówienia tematu. Oczywiście, publikacja źródłowa nie jest miejscem na szersze opracowanie monograficzne. Ale na pewno obszerniejszy tekst wstępny sprawiłby, że zebrane w tomie dokumenty lepiej pokazałyby swoją użyteczność, a sam tom byłby jeszcze ciekawszy. Bardzo liczę na to, że niedługo ujrzymy kolejną publikację, która dostarczy nam tak potrzebnego syntetycznego ujęcia tematu Sejmu i sejmików żydowskich w Koronie.

Na koniec warto dodać, że omawiana książka jest jednym z dwóch efektów wspomnianego projektu badawczego. Drugim jest portal o niemal identycznym tytule: Żydowski samorzad ziemski w Koronie, publikujący ponad 2000 dokumentów źródłowych (zob. http://www.ziemstwa.judaistyka.uj.edu.pl; 25 marca 2021 r. było to 2001 dokumentów). Teksty te przygotowane zostały według tych samych zasad, co źródła w omawianej 
publikacji, a ponadto zindeksowane i udostępnione w przeglądarce oferującej proste i zaawansowane kryteria wyszukiwania. Portal jest już dziś wielokrotnie obszerniejszy niż książka - należy więc mieć nadzieję, że ten wyjątkowo wartościowy projekt będzie kontynuowany i rozwijany.

Marcin Wodziński (DD https://orcid.org/0000-0002-0281-6391

Uniwersytet Wrocławski wodzinsk@uni.wroc.pl 